\title{
OVERVIEW OF WORKER CHARACTERISTICS, USE OF PPE, HYGIENE OF INDIVIDUALS, AND CONTACT DERMATITIS ON METAL COATING HOUSEHOLD INDUSTRY WORKERS
}

\author{
Renticabella Praharanie Edytya, Lilis Sulistyorini \\ Department of Environmental Health, \\ Faculty of Public Health, Airlangga University, Surabaya, Indonesia \\ Correspondence Address: Renticabella Praharanie Edyta \\ Email : renticapraharanie@gmail.com
}

\begin{abstract}
The use of personal protective equipment and personal hygiene is a factor that affects the occurrence of contact dermatitis. The aim of this study is to describe characteristics of workers, use of PPE, personal hygiene, and contact dermatitis in workers. This research is descriptive research with cross sectional design. This research used total populated sampling with 20 respondents in metal household coating industry of Waru and Candi Subdistrict, Sidoarjo. The results showed that the majority of workers $55 \%$ were $26-35$ years old, $50 \%$ with $2-3$ years working years, $50 \%$ with contact frequency $<150$ times and $>150$ times, $30 \%$ with exposure time 3.25 hours/day, 5 hours/day, and 8 hours/day. The highest percentage of APD frequency glove use is often $66 \%$ of industry Y, frequency is sometimes $58 \%$ industry $\mathrm{Z}$, and frequency is never $17 \%$ industry $\mathrm{Y}$. The highest percentage of APD frequency boot $\mathrm{APD}$ often $50 \%$ in industry $\mathrm{X}$ and $\mathrm{Y}$, frequency is sometimes $50 \%$ industry $\mathrm{X}$, and the frequency is never $50 \%$ industry Y. Personal hygiene is done by $50 \%$ of industrial workers $\mathrm{X}, 17 \%$ of industrial workers $\mathrm{Y}$, $58 \%$ of industrial workers $\mathrm{Z}$ and personal hygiene is not good done by $50 \%$ of industrial workers $\mathrm{X}, 83 \% \mathrm{Y}, 42 \%$ of industrial workers Z. Contact dermatitis experienced $100 \%$ industrial workers X, $83 \%$ of industrial workers $\mathrm{Y}$, and $83 \%$ of industrial workers $\mathrm{Z}$ in the form of skin irritation of hands and feet. The advice given is to provide counseling on matters that can cause contact dermatitis in workers.
\end{abstract}

Key word : characteristics of workers, use of PPE, personal hygiene, contact dermatitis

\section{ABSTRAK}

Penggunaan alat pelindung diri dan kebersihan perorangan merupakan faktor yang mempengaruhi terjadinya dermatitis kontak. Tujuan penelitian ini adalah menggambarkan karakteristik pekerja, penggunaan APD, kebersihan perorangan, dan dermatitis kontak pada pekerja. Penelitian ini merupakan penelitian deskriptif dengan rancang bangun cross sectional. Penelitian ini menggunakan total populated sampling dengan jumlah responden 20 orang di industri rumah tangga pelapisan logam Kecamatan Waru dan Kecamatan Candi, Sidoarjo. Hasil penelitian menunjukkan bahwa mayoritas pekerja 55\% berusia 26-35 tahun, 50\% dengan masa kerja 2-3 tahun, $50 \%$ dengan frekuensi kontak $<150$ kali dan $>150 \mathrm{kali}$, 30\% dengan lama paparan 3,25 jam/hari, 5 jam/hari, dan 8 jam/hari. Persentase terbanyak penggunaan APD sarung tangan frekuensi sering $66 \%$ industri $Y$, frekuensi kadang $58 \%$ industri $Z$, dan frekuensi tidak pernah $17 \%$ industri $Y$. Persentase terbanyak penggunaan APD sepatu boot frekuensi sering 50\% pada industri $X$ dan $Y$, frekuensi kadang $50 \%$ industri $X$, dan frekuensi tidak pernah $50 \%$ industri $Y$. Kebersihan perorangan baik dilakukan oleh $50 \%$ pekerja industri X, $17 \%$ pekerja industri $Y, 58 \%$ pekerja industri $Z$ dan kebersihan perorangan tidak baik dilakukan oleh $50 \%$ pekerja industri $X$, $83 \%$ pekerja industri $Y, 42 \%$ pekerja industri $Z$. Dermatitis kontak dialami $100 \%$ pekerja industri $X, 83 \%$ pekerja industri $Y$, dan $83 \%$ pekerja industri $Z$ berupa iritasi kulit tangan dan kaki. Saran yang diberikan adalah pemberian penyuluhan terkait hal-hal yang dapat menyebabkan dermatitis kontak pada pekerja.

Kata kunci : Karakteristik pekerja, penggunaan APD, kebersihan perorangan, dermatitis kontak

\section{INTRODUCTION}

The chemical and metal industry is one of the industries that has begun to be noticed by the Government of the Republic of Indonesia (Ministry of Industry, 2014).
Data Center Statistics Year 2015 shows that the micro and small industries have risen $42 \%$ from the year 1991 to 2014 . The micro industry is an industry with a number of workers of one to four people, while the small industry has workers with a number 
of fifteen to nineteen (Central Bureau of Statistics, 2015). One industry that belongs to the small industry is a metal coating household industry.

Health can play a role in determining worker productivity. Workers who have a good health condition can increase productivity in working, while workers with decreased health conditions scan produce something less maximal. The less maximal outcome could later affect the low productivity of work (Suma'mur, 2014).

Illness due to work is a condition that can cause low working productivity. Some diseases that are classified into disease due to work are pnemoconiosis, chemical poisoning, dermatosis (skin disorder), occupational nerve disorders, and psychological mental disorders due to work. Some of these diseases have a sufficiently high prevalence of workers (Suma'mur, 2014).

Dermatosis as a result of work is a skin disorder that can be caused by working environment factors when workers do their job. This disease is the highest ranked disease to reach a percentage of $50-60 \%$. Usually the disease appears on the hands, arms, and fingers of the skin. This disease can cause discomfort in workers so that it can lead to decreased productivity of work (Suma'mur, 2014).

One of the factors that cause dermatosis-induced work is substances and chemicals, such as irritant chemicals and chemical sensitizers. Irritant material can stimulate the skin by dissolving the fat and then do the water intake from the skin layer, then the chemical will oxidize and redusi the chemical composition of the skin. The material sensitizer can be caused by organic chemicals with molecular structures that can join the egg whites and form antigens (Suma'mur, 2014).

Research conducted by (Miarastika, 2015) on metal coating industry workers with exposure to nickel chemicals shows that most workers have a 26-35 year's lifespan with a percentage of $40 \%$, most workers have long Work of 0-1 years with a percentage of $40 \%$, all workers have a long contact more than 8 hours/day with a percentage of $100 \%$, and the worker has an average contact frequency as many as 400 times in a day. The results of research conducted by (Miarastika, 2015) on metal coating industry workers with exposure to nickel chemicals showed that as many as $70 \%$ of workers experienced contact dermatitis and the worker did not use personal protective equipment. Workers who do not experience contact dermatitis as much as $30 \%$ and the worker also does not use personal protective equipment, so there is no worker in the metal coating industry that uses personal protective equipment (Miarastika, 2015). Another study conducted by (Parwitasari, 2017) showed the results that as many as $75 \%$ of metal coating workers in UD Jasa Merdeka exhaust Purbalingga experienced health complaints in the form of skin irritation. Metal coating workers at UD Jasa Merdeka have mostly used APD (personal protective equipment) in the form of rubber gloves and shoes, as well as a protective head made of cloth (Parwitasari, 2017).

The results of the research conducted by (Prasetyo, 2014) on construction workers in PT Wijaya Kusuma Contractors showed that as many as $87.5 \%$ of the construction workers exposed by cement do not use protective equipment in the form of gloves while working. The results of the study also showed that from 32 investigated workers were acquired that 10 workers from 28 workers who did not use the APD experienced the incidence of contact dermatitis. One worker of four workers who use APD also experienced contact dermatitis (Prasetyo, 2014).

The research conducted by (Putri, S.A., Nirmala, F., 2017) on motor workshop workers in the region of Kendari shows that as many as $95 \%$ of workers do not use PPE. Workers who do not use APD when performing the work and experiencing the symptoms of contact dermatitis are $79.3 \%$, while workers who use APD no one 
experience symptoms of contact dermatitis. The results of the study also showed that $19 \%$ of workers do not good personal hygiene. Workers who do personal hygiene is not good and experience the symptoms of contact dermatitis is as much as $17 \%$, while the worker who does good personal hygiene and experiencing the symptoms of contact dermatitis is as much as $62 \%$. The study aims to illustrate the characteristics of workers, the use of personal protective equipment, individual hygiene, and contact dermatitis on metal coating household industry workers.

\section{METHODS}

The type of this research isdescriptive research because researchers only describe research variables without giving certain treatment. This research used a cross sectional design. This research was conducted on three locations of metal coating household industry in Sidoarjo regency. This research was conducted in the industry of X metal plating in the village of Kepuhshipment, Waru Sub-district, Sidoarjo District, industrial metal plating Y industry in Durungbanjar village, Temple subdistrict, Sidoarjo Regency, and household industry Z-Metal coating in Durungbanjar village, Candi District, Sidoarjo Regency. The population ofis the entire worker of chromium metal coating and metal flushing parts. The research population is taken at three industrial locations of metal coating households due to a slight research population. Thus, the study population is 2 workers parts metal coating chromium household industry $\mathrm{X}$ in the district Waru, 6 workers coating parts and flushing metals metal household industrial chromium $\mathrm{Y}$, and 12 workers coating parts and Flushing Metal Industrial chromium home appliances $\mathrm{Z}$.

The study used a total populated sampling, so there are no calculations about large and way of sampling. The research variables used in this research are the characteristics of the worker, the use of personal protective equipment, the individual hygiene of workers, and contact dermatitis in the workers ' coating and rinsing of chromium metals. The data collected in this study is primary data. Primary Data is collected using method interviews to respondents using questionnaire instruments. The resulting datathen analyzed descriptively without the use of statistical calculations.

The usage variables of the APD gloves and boots are categorized according to the frequency of their use i.e. often, sometimes, and never asked the respondent through the questionnaire. Individual hygiene variables are categorized as good and not good. The category is not well earned when the total score of six questions related to individual hygiene reaches the number $0-6$, while the good category is obtained when the total score reaches the number 7-12. This research has received information from the FKM Ethics Committee No: 23-KEPK.

\section{RESULT}

The results of the study gained 20 respondents. Respondents were workers exposed to chromium chemicals i.e. workers who served in metal plating by using chromium and flushing metal after chromium plating.

\section{Age Overview}

Table 1. Respondents age description

\begin{tabular}{crrrrrr}
\hline \multirow{2}{*}{ Age } & \multicolumn{6}{c}{ Industry } \\
\cline { 2 - 7 } & \multicolumn{2}{c}{$\mathrm{X}$} & \multicolumn{2}{c}{$\mathrm{Y}$} & \multicolumn{2}{c}{$\mathrm{Z}$} \\
\cline { 2 - 7 } & $\mathrm{n}$ & $\%$ & $\mathrm{n}$ & \multicolumn{1}{c}{$\%$} & $\mathrm{n}$ & $\%$ \\
\hline $17-25$ & 0 & 0 & 1 & 17 & 5 & 42 \\
\hline $26-35$ & 1 & 50 & 4 & 66 & 6 & 50 \\
\hline $36-45$ & 0 & 0 & 0 & 0 & 1 & 8 \\
\hline$>45$ & 1 & 50 & 1 & 17 & 0 & 0 \\
\hline
\end{tabular}

Based on the Table 1, it is known that the household industry worker $\mathrm{X}$ has an age range of 26-35 years and $>45$ years with a percentage of $50 \%$ respectively. The 
Y household industry worker mostly has an age range of 26-35 years with a percentage of $66 \%$. Z household industry workers mostly have an age range of 26-35 years with a percentage of $50 \%$.

\section{Overview of the work period}

Table 2. Overview of the respondent's employment

\begin{tabular}{|c|c|c|c|c|c|c|}
\hline \multirow{3}{*}{$\begin{array}{l}\text { Work } \\
\text { Period }\end{array}$} & \multicolumn{6}{|c|}{ Industry } \\
\hline & \multicolumn{2}{|c|}{$X$} & \multicolumn{2}{|c|}{$\mathrm{Y}$} & \multicolumn{2}{|c|}{$Z$} \\
\hline & $\mathrm{n}$ & $\%$ & $\mathrm{n}$ & $\%$ & $\mathrm{n}$ & $\%$ \\
\hline $0-1$ & 0 & 0 & 0 & 0 & 4 & 34 \\
\hline $2-3$ & 0 & 0 & 3 & 50 & 7 & 58 \\
\hline $4-5$ & 0 & 0 & 1 & 17 & 1 & 8 \\
\hline$>5$ & 2 & 100 & 2 & 33 & 0 & 0 \\
\hline
\end{tabular}

According to Table 2, it is known that the household industry worker $\mathrm{X}$ has a working period of $>5$ years with a percentage of $100 \%$. The $\mathrm{Y}$ household industry worker mostly has a working period of 2-3 years with a percentage of $50 \%$. Z household industry workers mostly have a working period of 2-3 years with a percentage of $58 \%$.

\section{Old imagery of chromium display}

Table 3. Long exposure to chromium in respondents

\begin{tabular}{crr}
\hline Prolonged exposure & \multicolumn{1}{c}{$\mathrm{n}$} & \multicolumn{1}{c}{$\%$} \\
\hline 90 minute/day & 2 & 10 \\
3,25 hour/day & 6 & 30 \\
5 hour/day & 6 & 30 \\
8 hour/day & 6 & 30 \\
\hline Total & 20 & 100 \\
\hline
\end{tabular}

According to Table 3, it is known that most workers have a long exposure of 3.25 hours/day, 5 hours/day, and 8 hours/day with a percentage of $30 \%$.

\section{Contact Frequency Overview}

Table 4. Contact frequency of respondents to chromium

\begin{tabular}{clr}
\hline Contact frequency & $\mathrm{n}$ & \multicolumn{1}{c}{$\%$} \\
\hline$<150$ times & 10 & 50 \\
$>150$ times & 10 & 50 \\
\hline Total & 20 & 100 \\
\hline
\end{tabular}

According to Table 4, it is revealed that some workers have a contact frequency of $<150$ times and $>150$ times with the same percentage of $50 \%$.

\section{APD Usage Overview}

Table 5. Overview of the use of APD gloves on industry workers of $\mathrm{X}$, $\mathrm{Y}$, and $\mathrm{Z}$ household metal plating

\begin{tabular}{ccccccr}
\hline & \multicolumn{5}{c}{$\begin{array}{c}\text { Use of PPE } \\
\text { Gloves } \\
\text { Indu } \\
\text { stry }\end{array}$} & \multicolumn{5}{c}{} \\
\cline { 2 - 7 } & \multicolumn{1}{c}{ Always } & \multicolumn{2}{c}{ Sometimes } & \multicolumn{2}{c}{ Never } \\
\cline { 2 - 7 } & $\mathrm{n}$ & $\%$ & $\mathrm{n}$ & $\%$ & $\mathrm{n}$ & $\%$ \\
\hline $\mathrm{X}$ & 1 & 50 & 1 & 50 & 0 & 0 \\
$\mathrm{Y}$ & 4 & 66 & 1 & 17 & 1 & 17 \\
$\mathrm{Z}$ & 4 & 34 & 7 & 58 & 1 & 8 \\
\hline
\end{tabular}

Based on the Table 5, it is known that metal coating industry workers $\mathrm{X}$ often and occasionally use APD gloves, most of the Y metal coating industry workers often use the APD gloves with a percentage of $66 \%$, and most Metal coating industry workers $Z$ sometimes use the APD gloves with a percentage of $58 \%$. Based on that, the workers who use the APD gloves most often are the metal coating industry worker Y.

Table 6. Overview of use of APD boots on the X, Y, and Z household industry workers

\begin{tabular}{ccccrrr}
\hline & \multicolumn{5}{c}{ Use of PPE } \\
Gloves \\
Indu & \multicolumn{5}{c}{ stry } & \multicolumn{7}{c}{ Always } & \multicolumn{3}{c}{ Sometimes } & \multicolumn{2}{c}{ Never } \\
\cline { 2 - 7 } & $\mathrm{n}$ & $\%$ & $\mathrm{n}$ & $\%$ & $\mathrm{n}$ & $\%$ \\
\hline $\mathrm{X}$ & 1 & 50 & 1 & 50 & 0 & 0 \\
$\mathrm{Y}$ & 3 & 50 & 0 & 0 & 3 & 50 \\
$\mathrm{Z}$ & 7 & 58 & 4 & 33 & 1 & 8 \\
\hline
\end{tabular}


Based on the Table 6, it is known that metal coating industry workers $\mathrm{X}$ often and occasionally using the APD boots, metal coating industry workers $\mathrm{Y}$ often and never use the APD boots, and most of the coating industry workers Metal $\mathrm{Z}$ often uses the APD boots with a percentage of $58 \%$. Based on that, most frequent workers using the APD boots are the metal coating industry worker $Z$.

\section{Personal Hygiene Overview}

Table 7. Overview of contact dermatitis on Industrial Workers $\mathrm{X}, \mathrm{Y}$, and $\mathrm{Z}$ household metal plating

\begin{tabular}{ccccc}
\hline \multirow{2}{*}{ Industry } & \multicolumn{3}{c}{ Individual hygiene } \\
\cline { 2 - 5 } & \multicolumn{2}{c}{ Good } & \multicolumn{3}{c}{ Not Good } \\
\cline { 2 - 5 } & $\mathrm{n}$ & $\%$ & $\mathrm{n}$ & $\%$ \\
\hline $\mathrm{X}$ & 1 & 50 & 1 & 50 \\
$\mathrm{Y}$ & 1 & 17 & 5 & 83 \\
$\mathrm{Z}$ & 7 & 58 & 5 & 42 \\
\hline
\end{tabular}

\section{Contact Dermatitis Complaint Overview}

Table 8. Overview of contact dermatitis complaints

\begin{tabular}{lrr}
\hline \multicolumn{1}{c}{$\begin{array}{c}\text { Contact Dermatitis } \\
\text { Complaints }\end{array}$} & n & \% \\
\hline Swollen skin & 8 & 40 \\
Redness of the skin & 12 & 60 \\
Liquid-removing & 10 & 50 \\
vesicles & & \\
Vesicles wound peeling & 12 & 60 \\
Itching & 15 & 75 \\
Pain & 14 & 70 \\
Vesicles spread if liquids & 0 & 0 \\
regarding other skin & & \\
Flavoured & 16 & 80 \\
Burning Flavor & 9 & 45 \\
Dry blisters Skin & 13 & 65 \\
Shrinkage & & \\
Scaly and dry skin & 7 & 35 \\
Skin thickening & 9 & 45 \\
Cracked and chapped & 2 & 5 \\
Skin & & \\
\hline
\end{tabular}

Based on the Table 7, it is known that metal coating industry workers $\mathrm{X}$ performs good and ungood individual hygiene, most of the metal coating industry workers $Y$ perform ungood individual hygiene with a percentage of $83 \%$, And most metal coating industry workers $\mathrm{Z}$ perform good individual hygiene with a percentage of $58 \%$.

Based on the Table 8, it is known that most workers experience a sore taste complaint on the skin with a percentage of $80 \%$.

\section{Overview of Contact Dermatitis}

Table 9. Overview ofdermatitis contact on Industrial Workers $\mathrm{X}, \mathrm{Y}$, and $\mathrm{Z}$ household metal plating

\begin{tabular}{crrrr}
\hline \multirow{2}{*}{ Industry } & \multicolumn{3}{c}{ Contact Dermatitis } \\
\cline { 2 - 5 } & \multicolumn{2}{c}{ Ya } & \multicolumn{3}{c}{ Tidak } \\
\cline { 2 - 5 } & \multicolumn{1}{c}{ n } & \multicolumn{1}{c}{ n } & \multicolumn{1}{c}{$\%$} \\
\hline X & 2 & 100 & 0 & 0 \\
Y & 5 & 83 & 1 & 17 \\
Z & 10 & 83 & 2 & 17 \\
\hline
\end{tabular}

According to Table 9, it is known that all metal coating industry workers $\mathrm{X}$ undergo contact dermatitis with a percentage of $100 \%$, while the workers of the $\mathrm{Y}$ and $\mathrm{Z}$ metal coating industry are experiencing contact dermatitis with a percentage of $83 \%$.

\section{DISCUSSION}

The metal coating process which carried out on the household industry $\mathrm{X}$ metal resurfacing is different from the metal coating process done on the industry of the metal plating $\mathrm{Y}$ and $\mathrm{Z}$. Metal coating process in the household industry X Metal Coating using a hard chrome plating method, while the metal coating process in the $\mathrm{Y}$ and $\mathrm{Z}$ metal plating household industry uses decorative metal plating. The metal coating process of the third household industry can potentially cause the exposure of chromium, so that can result in the incidence of contact dermatitis due to hand contact with chemicals during chromium metal coating process and Metal flushing after chromium coated. 
The process of chromium metal coating on the household industry $\mathrm{X}$ metal plating were performed by two people. The two workers were inserting the metal that will be coated into the coating tub contained in a specially sealed room. The metal to be coated in a chromium plating tub is associated with the appliance, and the worker waits for several hours outside the room. The length of time for workers to wait for the chromium coating process varies, depending on the thickness of the metal. If chromium plating time is sufficient, then the worker will enter the room and take the metal that has been coated with chromium, then the worker wash the metal clean by using the flowing faucet water. Metals are usually coated with various chromium according to customer order, for example hydraulic, hydrolic wash, triplex roll, paper roll, and plastic roll.

Chromium metal coating process in the household industry of $\mathrm{Y}$ and $\mathrm{Z}$ metal plating has the same way. Workers in charge chromium plating incorporate metals using tools similar to hooks. The metal is inserted into the chromium plating body in about three seconds. The metal inserted into the chromium coating tub creates a yellowish flame splash. The metal that has been inserted into the coating body then inserted into the immersion in the rinsing tub. The metal is immersed in a rinsing tub for about four seconds. The yellow color in the metal disappears when the metal is rinsed using clean water on the rinsing tub, so that the remaining yellow chromium is left in the rinsing tub and causes water discoloration in the rinsing tub become yellowish.

Exposure of chromium is obtained by chromium plating workers by means of direct contact with chemicals with worker's skin. The workpiece of chromium plating can contact with chemicals through metals that have been coated with chromium. The finished metal coated with chromium will be yellowish and will then be held by the worker to be placed into the rinsing tub.
Contact Chromium chemicals with worker's skin are obtained from the hand contact of the worker with chromium coated metals. Metal flushing parts workers can contact with chromium chemicals when inserting their hands into the rinsing tub which is also mixed residual chromium inside. The water rinse can also be about the body and legs when the worker takes the metal from inside the rinsing tub.

\section{Characteristics of workers}

The age of workers in this research is determined by calculating the age of workers from birth time until the time of study. The results showed that most workers had aged at a range of 26-35 years with a percentage of $55 \%$. This research is in line with research conducted by (Fasya, A.H.Z., 2015) on metal coating industry workers which shows that some of the researched workers have a 26-35 year old with a percentage of $50 \%$.

Most of the workers in all three household industries are examined for their young age. The results showed that workers in the household industry X Metal Coating has a range of ages 26-35 years and $>45$ years, whereas workers in the household industry of metal plating $\mathrm{Y}$ has a range of age of 17-25 years, 26-35 years, and $>45$ Years, and workers on metal plating $\mathrm{Z}$ household industry has a range of ages 1725 years, 26-35 years, and 36-45 years. Most household industry workers of $Y$ and $\mathrm{Z}$ metal plating have a lifespan of between 26-35 years, whereas the household industry of metal plating $X$ has the same number of workers with the age of 26-35 years and workers aged $>45$ year.

The employee's employment is calculated based on the information done by the workers for the length of time workers work in the metal coating industry until the time of research is performed. Most workers have a working period of 2-3 years with a percentage of $50 \%$. The research is in line with research conducted by (Fasya, A.H.Z., 2015) which suggests that most workers in the metal coating industry have 
a working period between a range of 2-3 years with a percentage of $60 \%$.

The results of the questionnaire showed that the household industry worker $\mathrm{X}$ Metal coating entirely has a $>5$ year working period, then the household industry worker Metal coating $\mathrm{Y}$ has a working period of 2-3 years, 4-5 years, and $>5$ years, while industrial workers $Z$ Metal Coating Household has a working period of 0-1 years, 2-3 years, and 4-5 years. Workers in the household industry of metal coating Y mostly have a work period of 2-3 years with the number of three people and household industry workers metal plating Z Most have a working period of 2-3 years with a total of seven people. These results show that most of the workers are new workers. According to the description of one industry worker $Y$, workers who are not resistant to chromium will ask out by themselves then replaced with new workers. This can lead to new workers in the industry.

The length of exposure is calculated based on the length of time workers contact with chromium chemicals within one office day. Most workers have a long exposure of 3.25 hours/day, 5 hours/day, and 8 hours/day. The results of the research were not in line with research conducted by (Rachmasari, 2013) on metal craftsmen workers who showed that most workers had long exposure long with a percentage of $52.5 \%$.

The household industry worker $\mathrm{X}$ Metal Coating has an entirely long exposure of 90 minutes/day. This is because the worker is only responsible for inserting the workpiece that will be coated metal into a special room with Wakti about 10 minutes then left and awaited outside until the time the worker will enter the room to Take and rinse the workpiece for about 20 minutes. It is done three times in a day, so that if multiplied by 30 minutes multiplied by three times, then the length of exposure gained by the worker is 90 minutes/day. Metal coating industry workers $Y$ all have a working period of 8 hours/day. This is because workers work from 07.00 WIB to $16.00 \mathrm{WIB}$ and rest at $12.00 \mathrm{WIB}$ to 13.00 WIB. Metal coating industry worker $\mathrm{Z}$ has a long exposure of 3.25 hours/day and 5 hours/day. This is due to the change of workers from the chromium plating with nickel plating workers. Six working people start at 07.00-12.00 WIB, while six other workers work from 12.45-16.00 WIB.

Frequency of contacts is calculated based on the frequency of workers in direct contact with chromium. Workers who have a contact frequency of $<150$ times in one day are equal to the worker who has the frequency of contact $>150$ times in a day with a percentage of $50 \%$. The research was not in line with the research conducted by (Miarastika, 2015) which shows that the worker on nickel metal plating has a contact frequency 400 times the censure in one day.

Household industry workers $\mathrm{X}$ metal plating all have a contact frequency of $<150$ times/day. Household industry worker Metal coating $\mathrm{Y}$ mostly has a frequency of contact $>150$ times/day with the number of four out of six people. Industrial worker Tanga Metal coating $\mathrm{Z}$ has the same number of workers that have a contact frequency of $<150$ times with a worker who has a contact frequency $>150$ times. This is due to the change of worker or shift work, so that there are workers who must perform chromium metal plating first and then nickel metal coating and vice versa.

\section{Use of PPE}

The use of personal protective equipment is needed to protect the worker's body from direct contact with chemicals that cause contact dermatitis occurrence. The use of personal protective equipment seen in this research is the use of gloves while working and the use of boots by workers. The use of frequent gloves on industrial workers of household metal plating $\mathrm{X}, \mathrm{Y}$, and $\mathrm{Z}$ reaches $45 \%$ only, while the rest only occasionally use gloves, never even use gloves when working. 
Workers who usegloves frequently are on the household metal coating $\mathrm{Y}$ with a percentage of $66 \%$, then workers who sometimes use the most gloves are household industry workers $\mathrm{Z}$ plating with a percentage of $58 \%$. Workers who have never used the personal protective equipment in the form of gloves are the household industry worker of metal coating $\mathrm{Y}$ and $\mathrm{Z}$ which each have one worker who never use gloves while doing the job. This research is in line with research conducted by (Rachmasari, 2013) to metal craftsmen workers who show that there are $72.5 \%$ of workers using PPE APD in the form of gloves.

Some workers sometimes use gloves and never use gloves while doing the job claiming that the worker is uncomfortable if they have to use gloves when doing the job, so they decided not to use gloves. The gloves themselves can actually be a inhibitory factor for workers in order not to undergo contact dermatitis. Although the worker is there who uses gloves when doing the job, but there are workers who use gloves improperly. The research results in the $\mathrm{Z}$ metal coating industry stated that some workers were uncomfortable using long gloves while working, so that the workers cut their gloves to a short. It can actually be a risk factor of workers in the suffering of contact dermatitis because chromium can get into the skin of the worker if the gloves are not worn properly. However, there are workerswho know how to use proper and precise gloves, he is one of the workers in the household industry of metal coating $\mathrm{Y}$. Researched metal coating industry workers admitted that during this time There is still no socialization or counseling related procedures for the use of personal protective equipment in the form of good and precise gloves.

The use of APD boots on workers is often done by most workers in all three metal coating industries. The owner of the industry has provided boots at work to be used by workers in doing their work. The number of workers who use the APD frequently16 out of 20 workers or with a percentage of $80 \%$. The research was not in line with the research conducted by (Rachmasari, 2013) on metal craftsmen workers who showed that there were $2.5 \%$ of workers using APD boots.

Workers who often use boot shoes the most among the three industries of the household metal coating are workers in the $\mathrm{Z}$ household industry with the number of workers as many as seven people. Workers who have never used the boot shoes among the three industries of metal coating households are the workers of industrial Yas much as thirty people. Household industry workers metal plating $\mathrm{X}$ There are only two people, one worker often use boots and one other person sometimes use boots while doing the job.

The use of Boots is done in order to minimize the presence of chromium contacts with worker feet. This is because the remaining chromium in the metal flushing tub is sometimes still scattered on the floor and can be a possibility to contact with the workers ' feet, causing contact dermatitis. Some workers claim that workers are sometimes and never use boots because they are not comfortable to use when doing the job. Workers sometimes choose to use sandals when doing work.

\section{Individual hygiene}

The individual hygiene in this study is grouped into workers who have good and ungood individual hygiene. The grouping is based on scores on each questionnaire question consisting of a question of bathing habits at rest and after work, the habit of washing hands before contact with the material, the habit of hand washing after contact With the material, the habit of drying hands after washing hands, the habit of washing work uniforms, and the habit of cutting nails hand when long. Each of these questions will give a score of two if the answer is frequent, giving the score one if the answer is sometimes, and gives a zero score if the answer is never. Then, the whole 
score in total and generates the total score. If the total score is less than equal to six then workers have poor individual hygiene, but if the total score shows more than six results the worker has good individual hygiene. The number six is derived from the total score if the worker performs the whole question with the often divided two.

Good individual hygiene is done by most workers in the $\mathrm{X}$ metal coating industry and workers in the metal coating industry $Z$. The individual hygiene seen in this study is a habit of bathing during rest and after work, Habit of hand washing before contact with the materials, the habit of washing hands after contact with the material, the habit of drying hands after washing hands, the habit of washing the work uniforms, and the habit of cutting nails hand when long. The individual cleanliness often done by most workers is a habit of bathing during rest and after work with a percentage of $50 \%$, habit of hand washing after contact with material with a percentage of $90 \%$, and the habit of cutting nails When the length with a percentage of $50 \%$.

Personal hygiene that is rarely done is a habit of washing work uniforms with a percentage of $35 \%$ and the habit of hand washing before contact with the material with a percentage of $15 \%$, then the cleanliness of the individual that is not done by all workers are habit of drying hands after washing hands with $0 \%$ percentage. Employees who perform good personal hygiene are 9 out of 20 workers with a percentage of $45 \%$. This research is not in line with the research conducted by (Putri, S.A., Nirmala, F., 2017) stating that the motorcycle workshop worker in the working area of Kendari city that performs individual cleanliness is not good is a number of $81 \%$.

\section{Contact Dermatitis}

Complaints of contact dermatitis experienced by workers vary depending on worker and subjective. The most common complaint experienced by workers is the skin with a percentage of $80 \%$. The flavor is obtained by a worker who is exposed to sparks from chromium during the process of coating the metal with chromium. Injuries that are still new when exposed to the spark will be felt sore by some workers. The five complaints of contact dermatitis most experienced by the worker is a taste of sore, itching, pain in the affected area of chromium, dried blisters of the skin shrinkage, then redness of the skin and wounds when vesicles exfoliate. This research is not in line with the research conducted by (Fasya, A.H.Z., 2015) which shows that the workers of metal coating industry are most experiencing erythema complaint that is reddish-coloured skin with a percentage of $80 \%$.

According to research conducted workers in Kelurahan Merdeka Kota Medan obtained the results stated that 14 of the 17 respondents experienced symptoms of contact dermatitis with a percentage of $82.4 \%$. The symptoms experienced by these workers are itching, heat, redness that is felt after contact with chemicals in the workshop. Based on Permenkes Number 5 year 2014 It is known that irritant contact dermatitis can be experienced by some people who have a risk of being exposed by irritant material, have a contact history with irritant material within a certain period of time, laundry worker, Workers of cooks, building workers, mechanics, and hairdressers, as well as someone who has a history of atopic dermatitis (Ministry of Industry, 2014). Complaints of perceived contact dermatitis on the skin differ in each patient depending on the irritant properties. Common symptoms include itching, redness of the skin area exposed to the contact of the irritant material, even sometimes followed by a sense of heat, sore, and burning (Ministry of Industry, 2014).

Contact Dermatitis is spread evenly to all workers in the metal coating industry studied. All metal coating industry workers $\mathrm{X}$ experienced contact dermatitis and worker is coating part worker. Five of the 
six workers in industry $\mathrm{Y}$ also undergo contact dermatitis consisting of two working parts coating workers, two worker parts rinsing section, and one worker part coating and rinsing. Ten of the twelve metal coating industry workers $\mathrm{Z}$ also undergo contact dermatitis consisting of a single worker's coating section, seven workers flushing parts, and two workers part coating and rinsing. Seventeen of the investigated workers experienced contact dermatitis with a percentage of $85 \%$. The research is in line with the research from (Putri, S.A., Nirmala, F., 2017) stating that the motorcycle workshop worker in the working area of Kendari city that experience the symptoms of contact dermatitis is as much as $79.3 \%$.

Contact Dermatitis experienced by workers in this study can be caused due to contact workers with chromium chemicals. Contact Dermatitis on this research is an irritation to the skin of the worker both on the hands and feet of the worker. The average worker has contact dermatitis on the skin of the hand, but when the observation on the foot skin is also found irritation of contact dermatitis. The symptoms of contact dermatitis are most noticeable in the hands and, the skin became reddish and also there are scars due to contact with chromium irritant material that has colored blackish. One industry worker of $\mathrm{X}$ admitted that he rarely used personal protective equipment in the form of gloves as well as boots because it felt uncomfortable in using it. It can certainly be a risk factor for contact dermatitis in workers.

\section{CONCLUSION}

Most of the metal coating industry workers were 26-35 year old. The workers mostly have a 2-3-year employment period. The long exposure most experienced by the worker is 3.25 hours/day, the length of exposure 5 hours/day and the length of exposure 8 hours/day in the same amount. The number of workers who have a contact frequency of $<150$ times/day equals the number of workers who have a contact frequency $>150$ times/day. Most workers often and occasionally use gloves while working and often use boots while working. Individual cleanliness most performed by the worker is the habit of bathing during rest and after work, the habit of washing hands with soap after doing the work, and the habit of cutting the nail of the hand. The most complaint by the worker is the taste of sore, itching, pain, dry blisters of the skin, redness of the skin, and wound arising when vesicles peel off. Most workers experience contact dermatitis.

The advice provided is to provide counseling by the manpower or UPT K3 officer to the worker regarding the correct and proper use of personal protective equipment, so as to avoid the direct contact of chemicals with worker's skin that may result in contact dermatitis events. The introduction of counseling should also be done to the industry owner so as to provide hand-washing soap for workers, so that workers do not use cream soap to wash hands. In addition, the poster forging related to the correct and precise application of APD can also be done in the workplace.

\section{REFERENCE}

Central Bureau of Statistics, 2015. Statistik 70th Indonesia Merdeka. Jakarta :

Fasya, A.H.Z., 2015. Analisis Penggunaan Kromium pada Pelapisan Logam dan Kondisi Kulit Tangan Pekerja Industri rumah tangga Pelapisan Logam CV X di Sidoarjo. Skripsi. Universitas Airlangga.

Ministry of Industry, 2014. Kemenperin Prioritaskan Pengembangan Industri Kimia dan Logam.

Miarastika, N., 2015. Analisis Kadar NIkel Limbah Cair dan Gangguan Kesehatan Kulit Pekerja Home Industri Pelapisan Logam di Desa Sugihwaras Kecamatan Candi Kabupaten Sidoarjo. Skripsi: Universitas Airlangga. 
Parwitasari, H.E.R., 2017. Hubungan Kadar Kromium di Udara dengan Kromium dan Kreatninin dalam Darah serta Keluhan Kesehatan Pekerja Pelapisan Logam UD Jasa Merdeka Knalpot di Purbalingga. Skripsi : Universitas Airlangga.

Prasetyo, D.A., 2014. Faktor-faktor yang Berhubungan dengan Dermatitis Kontak Iritan pada Tangan Pekerja Konstruksi yang Terpapar Semen di PT. WIjaya Kusuma Contractors Tahun 2014. Skripsi. Universitas Islam Negeri Jakarta.

Putri, S.A., Nirmala, F., A., 2017. Faktorfaktor yang Berhubungan dengan Gejala Dermatitis Kontak pada
Pekerja Bengkel Motor di Wilayah Kota Kendari Tahun 2016. Jurnal Ilmiah Mahasiswa Kesehatan Masyarakat, 2(6), pp.250-257.

Rachmasari, N., 2013. Faktor-faktor yang Berhubungan dengan Kejadian Dermatitis Kontak Iritan pada Pengrajin Logam di Desa201 Cepogo, Kecamatan Cepogo, Kabupaten Boyolali. Jurnal Kesehatan Masyarakat, 2(1), pp.205-214.

Suma'mur, 2014. Higiene Perusahaan dan Kesehatan Kerja (Hiperkes). Jakarta : CV Sagung Seto. 